\title{
Effects of Student Teams-Achievement Divisions Cooperative Learning with Models on Students' Understanding of Electrochemical Cells
}

\author{
Ataman Karaçöp ${ }^{1}$ \\ ${ }^{1}$ Department of Elementary Science Education, Kafkas University, Education Faculty, Turkey \\ Correspondence: Ataman Karaçöp, Department of Elementary Science Education, Kafkas University, Education \\ Faculty, Kars, Turkey. Tel: 90-474-225-1259. E-mail: ataman.karacop@gmail.com
}

Received: May 7, 2016

Accepted: June 15, 2016

Online Published: October 26, 2016

doi:10.5539/ies.v9n11p104

URL: http://dx.doi.org/10.5539/ies.v9n11p104

\begin{abstract}
The aim of this study was to determine the effect of Student Teams-Achievement Divisions cooperative learning with models on academic achievements of undergraduate university students attending classes in which the electrochemical cells. The sample of research was comprised of 70 students from first class of science teacher education program during the academic year 2014-2015. The data obtained by the Electrochemistry Achievement Test (EcAT). The study was carried out in three different groups. The research groups were randomly assigned as the cooperative learning with models group (CLMG), the cooperative learning group (CLG), and the control group (CG). The data obtained by the instrument was evaluated through descriptive statistics, one-way ANOVA, and ANCOVA. The results indicated that teaching electrochemical cells via STAD with Model method was more effective than the traditional teaching method and only STAD in increasing academic achievement. In addition, according to the EcAT results, students' high levels of misunderstanding show that there are indicative of some deficiencies in teaching of the electrochemical cells in the molecular level.
\end{abstract}

Keywords: student teams-achievement divisions, using models, electrochemical cells

\section{Introduction}

There is a relationship between the development level of countries and the advancement of technology. Thus, teaching science is of great significance. Student-centered education is considered to increase successfulness of students. In order to contribute to success, there is a need for designing teaching activities which put focus on learners themselves. It is vital that learners are provided with activities in which they can have their own experiences so that they can develop skills such as critical thinking, communication, researching and questioning, problem solving, reasoning, and linking obtained knowledge. The recent prominent active learning approaches have been widely accepted. Cooperative learning, in this sense, is one of the most commonly used active learning methods lately (Aydoğdu, 2012). In the 21st century, people need the skills to launch and maintain cooperative efforts to manage the increasing interdependence among regions, countries, organizations, communities, and individuals. Schools may be the primary setting in which individuals can learn how to do so, primarily through participating in cooperative learning activities (D. Johnson \& R. Johnson, 2014).

The efforts to realize the cooperative learning applications in physical science education are based on the idea that the learning is a social activity. Learning and understanding does not realize only by an individual's taking place in a social environment. Meaningful learning activities occur via activities that the individual realize through constant and active interaction in the social environment (Brown \& Cole, 2000; Chan, 2014; Erlandson, Nelson, \& Savenye, 2010; Kapur \& Kinzer, 2007; Zacharia, Xenofontos, \& Manoli, 2011). In other words, the meaning is configured by sharing the new information through social environment and interaction. Learning through interaction in social environment requires efforts students to look for the solution of a problem, to understand learning subjects and to create an outcome as a group of and in coordination. Learning occurs as a result of cooperative efforts that individual conducts with the peers and individual, which are more talented than themselves (D. Johnson \& R. Johnson, 2014; Moreno, 2009; Zacharia et al., 2011).

In recent years, studies involving cooperative learning, one kind of student-centered approach have emerged as an internationally important area of social science research among researchers (Slavin, 2011). Cooperative 
learning is the instructional use of small groups so that students work together to maximize their own and each other's learning (Johnson \& Johnson, 2014). "While researchers generally agree that cooperative learning can have a positive effect on student achievement, there remains a controversy about why and how various cooperative learning methods affect achievement and, most importantly, under what conditions cooperative learning has these effects" (Slavin, 2015). Many studies have been conducted in different settings of education, using different kinds of cooperative learning techniques. Such techniques are Learning Together (LT), Jigsaw Grouping, Teams-Games-Tournaments (TGT), Group Investigation (GI), Student Teams Achievement Division (STAD), and Team Accelerated Instruction (TAI). A series of research studies have found an important relationship between the higher cognitive and affective outcomes and cooperative learning approaches (Doymus, Karacop \& Simsek, 2010; D. Johnson \& R. Johnson, 2005; Okur \& Doymus, 2012; Sharan, 2014; Tran \& Lewis, 2012a; Tran \& Lewis, 2012b; Tran, 2014; Zacharia et al., 2011). When does it make sense to study together with another person? There is a general answer to this question. "It is when the group task involves a group reward based on the learning progress of each group member, which means that a team's success depends on each individual member's learning, as in Student Team-Achievement Divisions (STAD)" (Sharan, 2014). In the STAD heterogeneous groups are created. The students in the group are motivated to learn to help each other to realize the goals and be successful (Khan \& Inamullah, 2011).

STAD has been used in such diverse subject areas as math, language, arts, social studies, and science. The STAD method has consistently been proved to be among the most simple and effective CL methods in improving student achievement of well-defined objectives in various subjects (Adesoji \& Ibraheem, 2009; Khan \& Inamullah, 2011; Sharan, 2014; Tiantong \& Teemuangsai, 2013; Tran, 2014). STAD is a cooperative learning way in which the students help themselves and also their group friends learn in small heterogeneous groups. This method is conducted as the students get prepared for end of subject or weekly exams by teaching the course contents, worksheets, test applications presented by the teacher to each other through the activities they perform together. In STAD, collective contribution to the success of the group is in the foreground. That's why; there is a common goal addiction which covers all the group members' learning the course content. This enables the students, who have higher success in achieving this collective goal effort, to support others and be a teacher to them. As a result of collaborative studies progressing this way, it is enabled to raise sharing and successful individuals with developed social skills which is the need of modern society (Jalilifar, 2010; Khan \& Inamullah, 2011; Sharan, 2014; Slavin, 2014; Tiantong \& Teemuangsai, 2013; Tran, 2014).

Concrete models have a key role for teaching science concepts. Science instructors in teaching or directing students to perform an experiment might not be sufficient to help students understand important concepts at molecular level. Instructors might consider using visualization tools to help students visualize concepts at the molecular level and then connect these concepts to the corresponding macroscopic procedure or features (Adadan, 2014b; Supasorn et al., 2014). Visualization tools such as models stimulate more than one part of brain by offering an opportunity to learn by doing-living which necessarily results in increased retention of knowledge. In addition, they pave the way for the targeted success by letting learners make sense of the knowledge (Gilbert, 2005; Russell \& Kozma, 2005; Tasker \& Dalton, 2006).

Models help learners concentrate better on the topic, since they are interesting. They also facilitate learning because they appeal to more than one sense by simplifying an event. The social interaction between peers as well as their teacher may benefit from the integration of models (Adadan, 2014a; Ardac \& Akaygun, 2004; Liu, 2006; MacKinnon, 2003; Mayer, 2003; Merritt et al., 2007; Schwartz \& White, 2005). Learning is easier when new knowledge is associated with what was previously learnt. Models accelerate learning by teaching new knowledge on the basis of the former knowledge. They also shorten the learning time and facilitate permanent learning by reinforcing the obtained knowledge (Moreno \& Valdez, 2005; Philipp, Johnson, \& Yezierski, 2014).

Electrochemistry is a subject of science that the researchers and teachers have considered as both high school and college students have difficulty in learning it and they have a variety of conceptual misunderstandings about it. The reason why the electrochemistry is considered so difficult is that these subjects are abstract and there is a need for knowledge in different disciplines in learning of these subjects. For example, understanding the events that occur in electrochemical cells and electrolysis is directly related to the knowledge on electricity subjects in physics, the structure and properties of matter in chemistry and the particulate structure of matter, and mathematical process knowledge. The studies in the field of science education focus on identifying students' conceptual misunderstandings on electrochemistry subjects. Also, some studies have been conducted on how to achieve more effective teaching of these subjects and by which methods and materials. In addition to the studies of high school and university students, as well as teacher candidates and teachers have been included in the studies (Doymus et al., 2010; Ekiz, Kutucu, Akkuş, \& Boz, 2011; Garnett \& Treagust, 1992a, 1992b; Lin et al., 
2002; Loh, Subramaniam, \& Tan, 2014; Ogude \& Bradley, 1994, 1996; Osman \& Lee, 2014; Özkaya, 2002; Sanger \& Greenbowe, 1997a, 1997b). Ekiz et al. (2011) investigated pre-service chemistry teachers' understandings and misconceptions regarding the electrolytic cells in electrochemistry. Results revealed that pre-service chemistry teachers could not distinguish electrolytic cells from galvanic cells. Also, they could not distinguish the electrodes as anode and cathode in electrolytic cells, so they could not predict the product of the electrolysis correctly. In this study, it was tried to reveal both the effect of cooperative learning STAD method in university students' learning of electrochemistry subjects and the conceptual misunderstanding of the students.

As well as in other subjects of chemistry, also regarding the subject of electrochemical cells, it is important to understand the chemical events that occur, in macroscopic events, and the microscopic and symbolic level. Conducted studies showed that although the students know chemistry subjects, the meaningful learning does not occur because they cannot identify them in three levels (Adadan et al., 2009; Merritt et al., 2007; Philipp et al., 2014). It has been stated that the students have some misconceptions in electrochemistry subjects that this situation is mostly due to the lack of these three levels of learnings. In learning of electrochemistry, macroscopically the students are required to examine the process of electrolyte and non-electrolyte solutions, electrolysis process and electrochemical cell processes. At the same time, microscopically the students also need to understand the ions and electrons movements in the electrochemical processes occurred. However, symbolically the students are required to express the electrochemical processes with mathematical formulas, equations and processes. The students especially have difficulties in understanding the chemical processes microscopically (Adadan, 2014b; Doymus et al., 2010; Karacop \& Doymus, 2013; Karsli \& Çalik, 2012; Lee \& Osman, 2011). The research in science education shows that preservice teachers' existent misconceptions are reflected in their teaching career unless they are provided with appropriate learning environment where they can treat their misconceptions. A number of studies advise encouraging preservice teachers to actively research their field and participate in learning environment where the aim is to alter the misconceptions that hinder restructuring of knowledge (Adadan, 2014b; Çalık \& Ayas, 2005; Papageorgiou et al., 2013).

The aim of this study was to determine the effect of Student Teams-Achievement Divisions cooperative learning with models on academic achievements of first year university students attending classes in which the electrochemical cells. The research questions of the present study are:

1) Does using STAD with model, only STAD and the traditional method in the teaching of electrochemical cells create a significant difference in the success of students?

2) What is the level of conceptual understanding of the research groups on electrochemical cells?

\section{Method}

\subsection{Research Design}

The design used in this study was the pretest-posttest non-equivalent comparison-group design and one control group and two experimental groups were selected, and each treatment randomly was assigned. "In analyzing the effects of teaching materials or teaching methods in different schools and classrooms, it is more convenient to use the quasi-experimental research design. A quasi-experimental design in which participants are not randomly assigned to the groups, instead, there are naturally occurring groups" (Creswell, 2014).

\subsection{Sample}

The sample of research was comprised of 70 students from first class of science teacher education program. It was studied with three groups, two of them were experimental groups and one of them was control group. These were cooperative learning with models group $(\mathrm{CLMG})(\mathrm{N}=24)$ in that Student Team Achievement Division (STAD) method of cooperative learning and model used together, cooperative learning group (CLG) $(\mathrm{N}=24)$ in that only Student Team Achievement Division (STAD) method of cooperative learning was used and control group $(\mathrm{CG})(\mathrm{N}=22)$ in that traditional teaching was used. In Turkey, students take an exam after completing upper secondary education to enter tertiary education. The samples of this study have been admitted to this department only after they have successfully passed this exam. But students of science education come to university from different regions of Turkey.

\subsection{Instruments}

To verify the effects of teaching methods on the academic achievements of first year university students in the electrochemical cells, each group of students was given the Electrochemistry Achievement Test (EcAT) at the beginning and at the end of the study. 


\subsubsection{Electrochemistry Achievement Test (EcAT)}

EcAT consisted of 10 questions, 8 being open-ended and 2 being multiple-choice, which measured students' comprehension of electrochemical cells at molecular level. The misconceptions present in the literature were taken into account in the preparation of questions and the questions were prepared so that they covered the whole subtopics of the electrochemical cells. The reliability coefficient of the EcAT was found to be 0.69. The answers from the EcAT were evaluated under two categories: "(1) scientific understanding (SU); answers including a part or the whole scientific opinions related to the question, (2) misunderstanding (MU); student answers that are different from the acceptable scientific answers" (Abraham et al., 1992; Doymus et al., 2010). Giving "10" points for each question in first category, EcAT pre and post-test scores were obtained. The students' answers about the misunderstandings were transcribed. The percentages of misunderstandings were separately calculated for CLMG, CLG, and CG. The drawing samples of statements regarding misunderstandings were also provided. The answers that did not contain scientific content as well as unanswered questions were not evaluated.

\subsection{Implementation}

Before the experimentation, EcAT was implemented in all groups as a pre-test. Then, each group studied lessons considering their research method. The researcher himself taught all groups for two-week duration due to time constraints. After two weeks instruction, posttest was administered to all groups. The subjects 'electrolysis vs. galvanic cell: differences?', 'set up and operation of an electrolytic cell', 'anode and cathode half-reactions in an electrolytic cell', and 'set up and operation of a galvanic cell, cell diagrams' were studied in all groups.

In firstly CLG, the students divided into cooperative groups. Then, the teacher explained electrochemical cells to students as abstract to students with reference to Student Teams Achievement Divisions (STAD) method of cooperative learning. In the STAD method, topics of the electrochemical cells were presented to the students in the form of a discussion or lecture method. Each group was given worksheets including explanation, questions and drawings of the events that occur in electrochemical cells. Afterwards, the students did the tasks assigned to them, discussing together. Students were given sufficient time to do their task. Finally, the students were given the quiz to answer independently. The role of individual student was determined by how much each student's quiz score exceeded his preset score. Thus, all groups received a progress score based on the performance of each student.

In CLMG, the students divided into cooperative groups. Next, the teacher explained electrochemical cells to students as abstract to students with reference to Student Teams Achievement Divisions (STAD) method of cooperative learning. Then, it was given an electrochemical cell to cooperative groups and it was wanted to design using three dimensional molecule models and play dough. İt was wanted to show events have been occurred anode and cathode at particulate level. In Figures 1 and 2, it was given a model prepared by students.

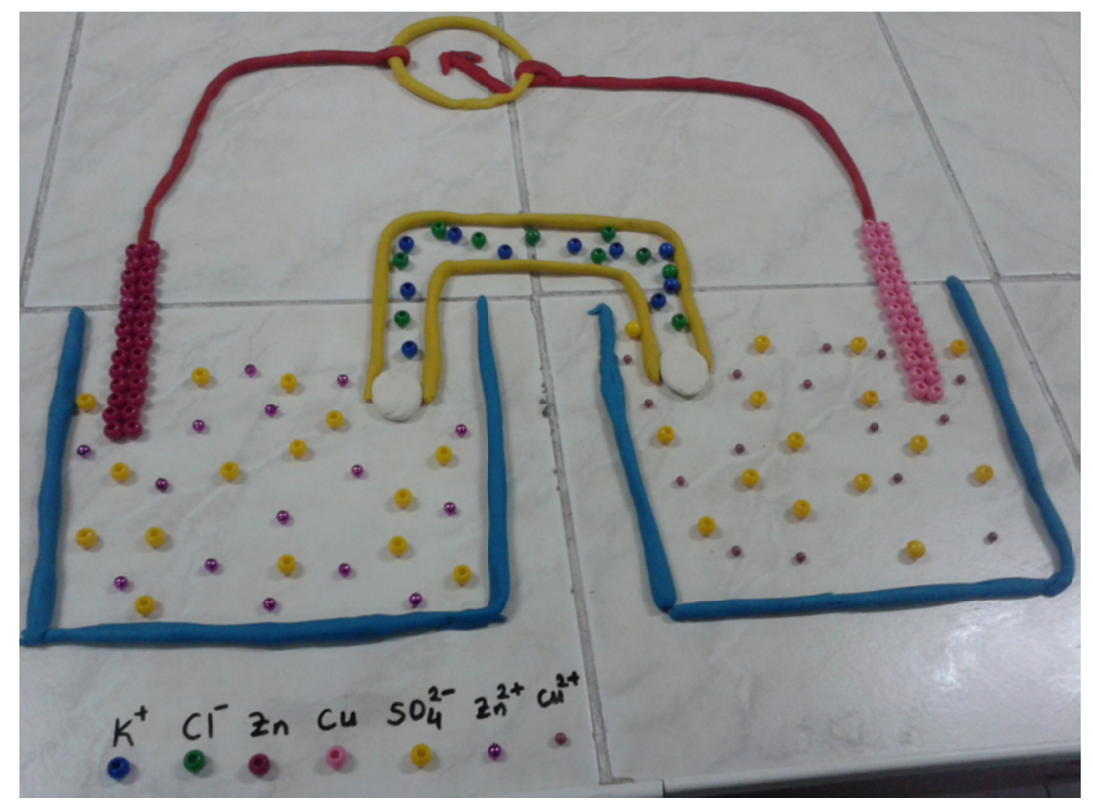

Figure 1. A model related to electrochemical cells prepared by students 


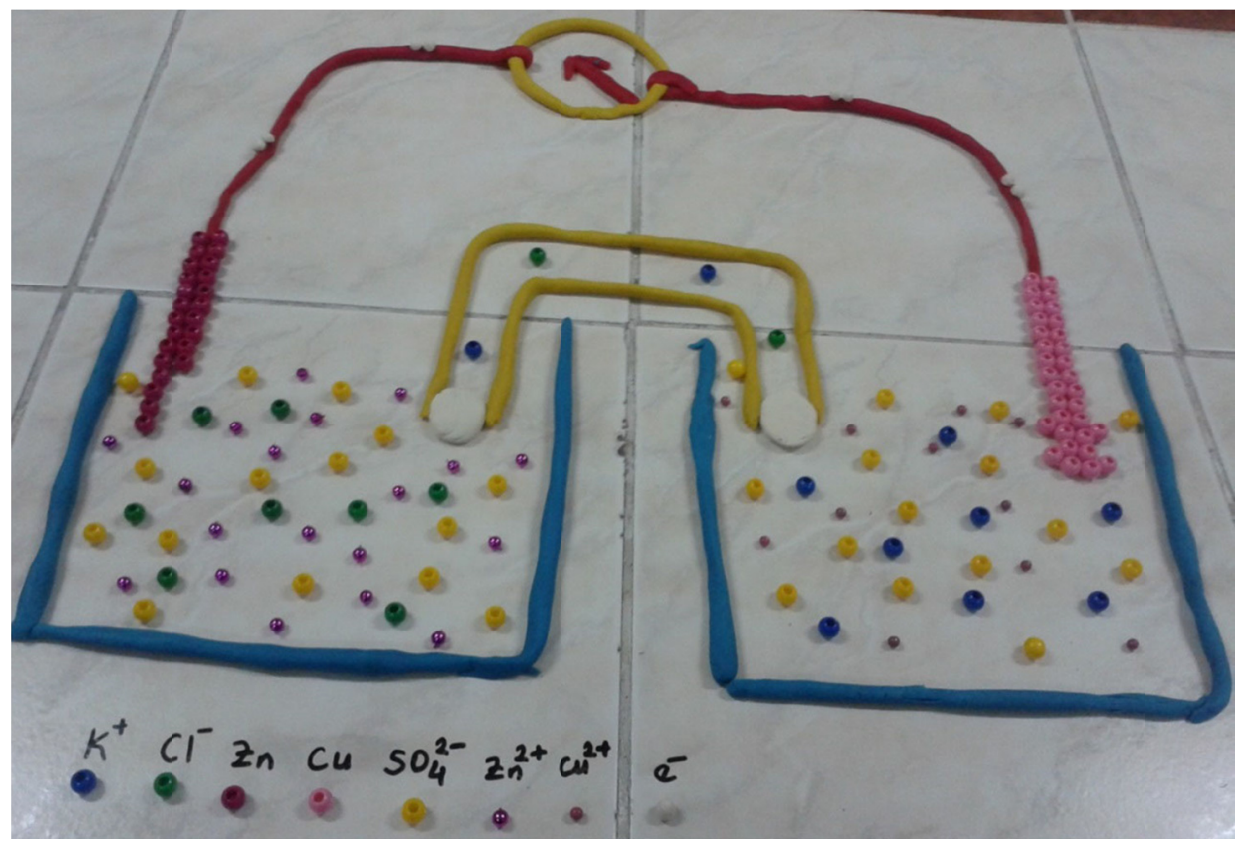

Figure 2. A model related to working electrochemical cells prepared by students

In the $\mathrm{CG}$, the teaching of the electrochemical cells subject was performed by traditional teaching methods. The teacher described the subjects with activities in the form of description, question-answer and entire class discussion by following the course materials that he/she prepared previously. The blackboard was used while the visual contents were presented. Also, problems requiring mathematical processes were solved. The subjects are used in the expression of presented visual. It also has solved problems that require mathematical operations. The students listened what was told while the teacher was describing the subjects, and they took the floor and they asked the questions to the teacher. And the teacher replied the questions and also when there were concepts that they did not understand the teacher provided additional information on these.

\subsection{Analysis of the Data}

The identifying statistics regarding pre and post EcAT scores of the students who participated in the study are calculated. One-way variance analysis was performed in order to compare the pre ECAT (One-way ANOVA) scores of the study groups. The responses that the students gave to the questions involving presentation at the molecular level taken place in the post test were converted to written expressions. Percentages of these expressions were calculated. One-way covariance analysis (ANCOVA) was performed in order to compare the post EcAT scores of the study groups by taking pre EcAT scores as the covariate. In order to reveal the effect of experimental application applied in the study, f value was calculated by using eta squared $\left(\eta^{2}\right)$ values. Cohen's classification " $(\mathrm{f}=0.1$ is deemed a small effect size, $\mathrm{f}=0.25$ a medium effect size, and $\mathrm{f}=0.4$ a large effect size $)$ " was used in interpretation of these values (Cohen, 1988).

\section{Results}

In this section, the findings obtained from the research into the effects of the use of the Student Teams Achievement Divisions method along with the models, only Student Teams Achievement Divisions method and traditional teaching methods in teaching electrochemical cells are presented.

\subsection{Findings Relating to the First Research Question}

Descriptive statistical values related to the pre and post EcAT scores of the study groups were shown in Table 1 . 
Table 1. Descriptive statistics for pre and post EcAT scores

\begin{tabular}{lcccc}
\hline Variable & Group & $\mathrm{N}$ & Mean & Std. Deviation \\
\hline EcAT pretest & CLMG & 24 & 24.17 & 15.581 \\
& CLG & 24 & 7.92 & 10.624 \\
& CG & 22 & 9.09 & 11.088 \\
\hline EcAT posttest & CLMG & 24 & 65.42 & 23.402 \\
& CLG & 24 & 44.17 & 22.051 \\
& CG & 22 & 38.18 & 20.848 \\
\hline
\end{tabular}

Table 1 presents the means of pre and post EcAT scores for each instructional treatment and the control group. The means of pre and post EcAT for the CLMG is larger than that for each of the other instructional treatment groups (CLG and CG). It is seen that students' mean scores for the pre/post-EcAT were not similar between the experimental and control groups. In order to determine whether there was a significant difference between the groups before the study according to the scores obtained from the pre-EcAT, one-way ANOVA was performed and the results are presented in Table 2 .

Table 2. ANOVA results for pre-EcAT scores

\begin{tabular}{lcccccc}
\hline $\begin{array}{l}\text { Dependent } \\
\text { Variable }\end{array}$ & Source & $\begin{array}{c}\text { Sum of } \\
\text { Squares }\end{array}$ & df & $\begin{array}{c}\text { Mean } \\
\text { Square }\end{array}$ & F & p \\
\hline EcAT pretest & Between Groups & 3897.587 & 2 & 1948.793 & 12.134 & .001 \\
& Within Groups & 10760.985 & 67 & 160.612 & & \\
& Total & 14658.571 & 69 & & & \\
\hline
\end{tabular}

When ANOVA results in Table 2 are examined, it was seen that there was a significant difference between mean scores of pre EcAT of the study groups $(\mathrm{F}(2.67)=12.134 ; \mathrm{p}<.05)$. The result of multiple comparison test was checked in order to determine between which groups there was a significant difference. LSD multiple comparison test results showed that CLMG's mean pre EcAT point was significantly different from other study groups (mean difference $=16,250$ and mean difference $=15076 ; \mathrm{P}<.05$ for the CLG and CG, respectively). However, it was found that there was not a significant difference between the mean pre EcAT scores of other two study groups (CLG and CG). It was understood from ANOVA results that the knowledge levels of the study groups on electrochemical cells were different prior to the experimental application.

Since it was found that there was a significant difference between the mean pre EcAT scores of the study groups, the correlation between these two scores were checked before comparing post EcAT scores. Pearson correlation analysis showed that there is a weak relation at the level of 0,225 between the pre and post EcAT scores of the study groups. One-way covariance analysis (ANCOVA) was performed in order to compare the post EcAT scores of the study groups by taking pre EcAT scores as the covariate. The results of one way ANCOVA were shown in Table 3. 
Table 3. ANCOVA results for post-EcAT scores

\begin{tabular}{lcccccc}
\hline Source & $\begin{array}{c}\text { Type III Sum of } \\
\text { Squares }\end{array}$ & df & $\begin{array}{c}\text { Mean } \\
\text { Square }\end{array}$ & F & p & $\begin{array}{c}\text { Partial Eta } \\
\text { Squared }\end{array}$ \\
\hline Corrected Model & $9587.463 \mathrm{a}$ & 3 & 3195.821 & 6.411 & .001 &, 226 \\
Intercept & 77325.115 & 1 & 77325.115 & 155.122 & .001 &, 702 \\
EcAT pretest & 6.759 & 1 & 6.759 & .014 & .908 &, 001 \\
Groups & 7436.077 & 2 & 3718.038 & 7.459 & .001 &, 184 \\
Error & 32899.680 & 66 & 498.480 & & & \\
Total & 214500.000 & 70 & & & & \\
Corrected Total & 42487.143 & 69 & & & & \\
\hline
\end{tabular}

(a) R Squared $=0.226$ (Adjusted R Squared $=0.190$ ).

Analysis results in Table 3 showed that there was a statistically significant difference between mean post ECAT scores of the study groups $\left(F_{(2,66)}=7.459 ; p<.05\right)$. In addition, the calculated effect size value $(f=0.47)$ was interpreted as the effect of the experimental application was high ( $\mathrm{f}>0.4$ ). The result of the Bonferroni multiple comparison test was examined in order to determine between which groups there was the significant difference in the post EcAT mean scores of the study groups. The results of multiple comparison test showed that CLMG's corrected mean scores significantly differed from CLG and CG (the mean difference between CLMG, CLG and $\mathrm{CG}$ is $21.657,27.613$ respectively; $\mathrm{P}<.05$ ). Whereas, it was seen that there was not a difference between post EcAT corrected scores of the other two study groups (mean difference between CLG and CG is 5.955; $\mathrm{p}>.05$ ).

\subsection{Findings Relating to the Second Research Question}

A content analysis was made for the answers, which were given by the students in the research group for the first and seventh tasks present in the EcAT post-test and remained out of those accepted scientifically correct. In Task 1 , the students were asked to show the type and number of ions in solutions, which were present in anode and cathode sections and salt bridge as a result of oxidation and reduction reactions realized while zinc-copper electrochemical cell was working, in molecular level. The expressions belonging to the answers of the students in the research group, which are in the misunderstanding category for the first task in the EcAT, and the percentages of these misunderstandings are shown in Table 4.

Table 4. The percentages of written expressions belonging to the MU category of Task 1 on EcAT

\begin{tabular}{|c|c|c|c|}
\hline Written expressions obtained from the incorrect drawings by students & CLMG & CLG & CG \\
\hline $\begin{array}{l}\text { It was shown that } \mathrm{Zn}^{2+} \text { ions increased in the anode section. It was shown } \\
\text { that } \mathrm{Cu}^{2+} \text { ions decreased in the cathode section. However, it was shown } \\
\text { that there was not any ion pass from salt bridge to anode and cathode } \\
\text { sections in order to ensure load balance while electrochemical cell was } \\
\text { working. }\end{array}$ & 20.8 & 12.5 & 40.9 \\
\hline $\begin{array}{l}\text { The difference in load balance caused by increase of } \mathrm{Zn}^{2+} \text { ions in the } \\
\text { anode section and decrease of } \mathrm{Cu}^{2+} \text { ions in the cathode section while } \\
\text { electrochemical cell was working was balanced by } \mathrm{SO}_{4}^{2-} \text { ions in the } \\
\text { electrolyte solution used in the sections instead of ion }\left(\mathrm{K}^{+} \text {and } \mathrm{NO}_{3}^{-}\right) \text {pass } \\
\text { from salt bridge to anode and cathode sections. }\end{array}$ & - & - & 4.5 \\
\hline $\begin{array}{l}\text { One } \mathrm{Zn}^{2+} \text { ion increase in the anode section was tried to be balanced with } \\
\text { one } \mathrm{NO}_{3}{ }^{-} \text {ion pass from salt bridge to this section while electrochemical } \\
\text { cell was working. In the same way, one } \mathrm{Cu}^{2+} \text { ion decrease in the cathode } \\
\text { section was balanced with one } \mathrm{K}^{+} \text {ion pass from salt bridge to this } \\
\text { section. }\end{array}$ & 29.2 & 45.8 & 9 \\
\hline
\end{tabular}


It was shown that $\mathrm{Zn}^{2+}$ ion decreased in the anode section and that $\mathrm{Cu}^{2+}$ ion increased in the cathode section. The difference in load balance caused by the change in ion numbers in the anode section while electrochemical cell was working was balanced by $\mathrm{SO}_{4}{ }^{2-}$ ions in the electrolyte solution used in the anode and cathode sections.

It was shown that $\mathrm{Zn}^{2+}$ ions decreased in the anode section and that $\mathrm{Cu}^{2+}$ ion increased in the cathode section. It was shown that there was not any ion pass from salt bridge to anode and cathode sections in order to remove the difference in load balance caused by the change in ion numbers in the anode section while electrochemical cell was working.

One $\mathrm{Zn}^{2+}$ ion decrease occurred in the anode section was balanced by one $\mathrm{K}^{+}$ion pass from salt bridge to this section while electrochemical cell was working. In the same way one $\mathrm{Cu}^{2+}$ ion increase in the cathode section was tried to be balanced with one $\mathrm{NO}_{3}{ }^{-}$ion pass from salt bridge to this section.

Note. Percentages were calculated on the base of the number of students in each groups numbers given in the table.

According to Table 4, the students in research groups correctly understood that $\mathrm{Zn}^{2+}$ ions increased in the anode section and $\mathrm{Cu}^{2+}$ ions decreased in the cathode section. It was seen that only some (4-17\%) of the students in the research group gave answers showing that $\mathrm{Zn}^{2+}$ ions decreased in the anode section and $\mathrm{Cu}^{2+}$ ions increased in the cathode section while the zinc-copper electrochemical cell was working. However, the students in all of these groups gave answers showing that there was not any ion pass (9-41\%) from salt bridge to anode and cathode sections in order to ensure load balance while electrochemical cell was working. It was also seen that the students in all groups gave answers $(9-46 \%)$ showing that the load balance was achieved in the case of one $\mathrm{Zn}^{2+}$ ion increase in the anode section by one $\mathrm{NO}_{3}{ }^{-}$ion pass from salt by one $\mathrm{K}^{+}$ion pass from salt bridge to this section. Only $4.2 \%$ of students in CLMG gave answers showing that the load balance was achieved in the case of one $\mathrm{Zn}^{2+}$ ion decrease by one $\mathrm{K}^{+}$ion pass, and in case of one $\mathrm{Cu}^{2+}$ ion increase by one $\mathrm{NO}_{3}{ }^{-}$ion pass, whereas some part of the students in $\mathrm{CG}(4.5 \%)$ gave answers showing that the load balance is achieved by $\mathrm{SO}_{4}{ }^{2-}$ ions in the electrolyte solution used in the anode and cathode sections. Some incorrect drawings by Students are given in Figure 3. 

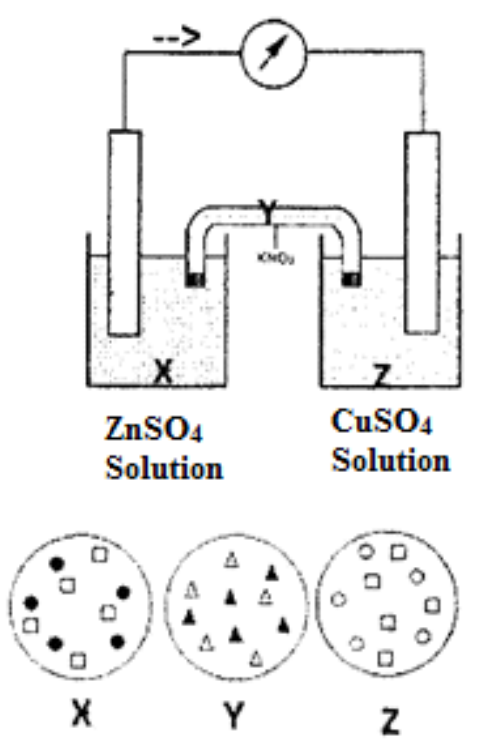

$\left(\mathrm{Zn}^{+2}: \bullet, \mathrm{Cu}^{* 2}: \mathrm{O}, \mathrm{K}^{*}: \Delta, \mathrm{NO}_{3}{ }^{*}: \boldsymbol{\Lambda}, \mathrm{SO}_{4}^{-2}: \square\right)$
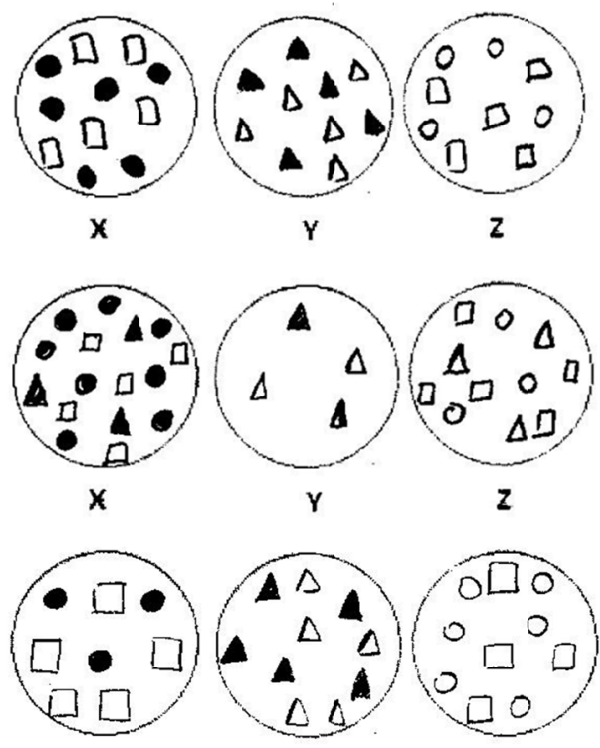

$x$
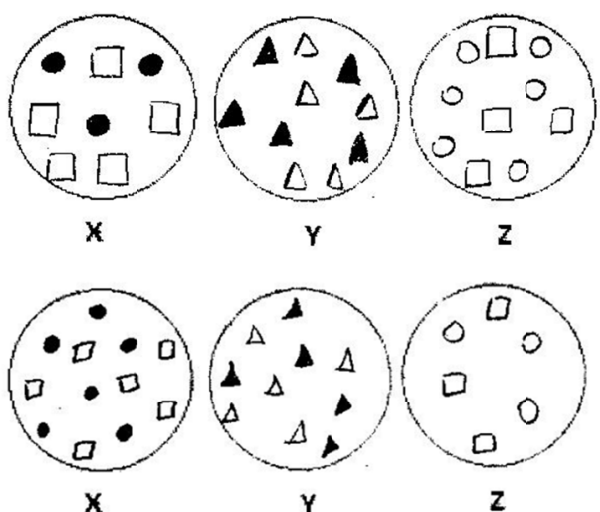

Figure 3. Some students' drawings in the misunderstanding category of Task 1 of the EcAT

In Task 7, $\mathrm{Zn}$ electrode used in the anode section and $\mathrm{Cu}$ electrode used in the cathode section of the zinc-copper electrochemical cell was marked as three parts (I: Upper, II: Middle and III: Lower). The first part was placed outside of the solution and the second and third part were placed inside the solution. The students were asked to show the changes in molecular level which occurred in electrodes as a result of oxidation and reduction reactions realized in the anode and cathode sections. The expressions belonging to the answers of the students in the research group, which are in the misunderstanding category for the task 7 in the EcAT, and the percentages of these misunderstandings are shown in Table 5.

Table 5. The percentages of written expressions belonging to the MU category of Task 7 on EcAT

\begin{tabular}{|c|c|c|c|}
\hline Written expressions obtained from the incorrect drawings by students & CLMG & CLG & $\mathrm{CG}$ \\
\hline $\begin{array}{l}\text { Matter-collecting occurs both in the parts of Copper electrode remaining } \\
\text { both inside and outside the solution as III (Lower) }>\text { II (Middle) }>\text { I (Upper). }\end{array}$ & - & - & 4.5 \\
\hline $\begin{array}{l}\text { Matter-deficit occurs in the parts of Copper electrode remaining inside the } \\
\text { solution respectively as III (Lower)>II (Middle), not any change occurs in } \\
\text { the part remaining outside the solution. }\end{array}$ & - & - & 9 \\
\hline $\begin{array}{l}\text { Matter-deficit occurs in the parts of Copper electrode remaining inside the } \\
\text { solution respectively as III (Lower)>II (Middle), whereas matter-collecting } \\
\text { occurs in the part remaining outside the solution. }\end{array}$ & - & - & 13.6 \\
\hline $\begin{array}{l}\text { Equal amount of matter-deficit occurs in the parts of Copper electrode } \\
\text { remaining inside the solution, not any change occurs in the part remaining } \\
\text { outside the solution. }\end{array}$ & 8.3 & 29.2 & 9 \\
\hline
\end{tabular}




\begin{tabular}{|c|c|c|c|}
\hline $\begin{array}{l}\text { Matter-collecting occurs in the parts of Copper electrode remaining inside } \\
\text { the solution respectively as III (Lower)>II (Middle), whereas } \\
\text { matter-deficit occurs in the part remaining outside the solution. }\end{array}$ & - & - & 4.5 \\
\hline $\begin{array}{l}\text { Matter-collecting occurs both in the parts of Copper electrode remaining } \\
\text { both inside and outside the solution as I (Upper)>III (Lower)> II (Middle). }\end{array}$ & - & - & 4.5 \\
\hline $\begin{array}{l}\text { Matter-deficit occurs in lower III (Lower) part of Copper electrode } \\
\text { remaining inside the solution, not any change occurs in the other two parts. }\end{array}$ & - & - & 13.6 \\
\hline $\begin{array}{l}\text { Matter-collecting occurs in lower III (Lower) part of Copper electrode } \\
\text { remaining inside the solution, not any change occurs in the other two parts. }\end{array}$ & - & - & 4.5 \\
\hline $\begin{array}{l}\mathrm{Cu}^{+2} \text { ions accumulate in the parts of Copper electrode remaining inside the } \\
\text { solution. }\end{array}$ & 4.2 & - & 4.5 \\
\hline $\begin{array}{l}\text { Matter-deficit occurs both in the parts of Zinc electrode remaining both } \\
\text { inside and outside the solution as III (Lower) }>\text { II (Middle) }>\text { I (Upper). }\end{array}$ & - & - & 4.5 \\
\hline $\begin{array}{l}\text { Equal amount of matter-collecting occurs in the parts of Zinc electrode } \\
\text { remaining inside the solution, not any change occurs in the part remaining } \\
\text { outside the solution. }\end{array}$ & 8.3 & 29.2 & 9 \\
\hline $\begin{array}{l}\text { Matter-collecting occurs in the parts of Zinc electrode remaining inside the } \\
\text { solution respectively as III (Lower)>II (Middle), whereas matter-deficit } \\
\text { occurs in the part remaining outside the solution. }\end{array}$ & - & - & 18 \\
\hline $\begin{array}{l}\text { Matter-collecting occurs in lower III (Lower) part of Zinc electrode } \\
\text { remaining inside the solution, not any change occurs in the other two parts. }\end{array}$ & - & - & 13.6 \\
\hline $\begin{array}{l}\text { Matter-deficit occurs in lower III (Lower) part of Zinc electrode remaining } \\
\text { inside the solution, not any change occurs in the other two parts. }\end{array}$ & - & - & 4.5 \\
\hline $\begin{array}{l}\mathrm{Zn}^{+2} \text { ions accumulate in the parts of Zinc electrode } \\
\text { solution. }\end{array}$ & 4.2 & - & 18 \\
\hline
\end{tabular}

When Table 5 is examined, it is seen that only the students in CG (27\%) gave answers showing that there is matter-collecting or matter-deficit in the first part of $\mathrm{Cu}$ electrode remaining outside the solution, marked as three parts (I: Upper, II: Middle and III: Lower ) used in cathode section of zinc-copper electrochemical cell. In naddition, these answers also showed that there are different amounts of matter-collecting (CG: 9\%) or matter-deficit (CG: 31.6\%; CLG: 29.2\%; CLMG: 8.3\%) in the rest parts ( II: Middle and III: Lower) of Cu electrode remaining inside the solution, were given. However, it was detected that there are also answers showing that there is matter-collecting (CG: 4.5\%) or matter-deficit (CG: 13,6\%)in lower part (III: Lower) of Cu electrode remaining only in the lowermost part of the solution. The students answers in research groups showed that there are in different amount of matter-collecting or matter-deficit in parts of $\mathrm{Cu}$ electrode remaining inside of the solution. Morover their answers showed that there was not any change (CG: 27\%; CLG: 29.2\%; CLMG: $8.3 \%$ ) in part of $\mathrm{Cu}$ electrode remaining outside of the solution.

In Table 5, the answers show that there is matter-deficit in the first part, which remained in the outside of the solution of $\mathrm{Zn}$ electrode used in the anode compartment of zinc-copper electrochemical cell and marked as three parts (I Upper, II: Middle and III: Lower), (CG: 22.5\%) are shown. It was also seen that there are different amounts of matter-collecting (CG: 18\%) or matter-deficit (CG: 4.5\%) in parts of Zn electrode remaining inside the solution (II: Middle and III: Lower).However, there are also answers showing that there is matter-collecting (CG: $13.6 \%$ ) or matter-deficit (CG: $4.5 \%$ ) in parts of Zn electrode remaining only in the lowermost part (III: Lower) of the solution. The answers of students in research groups demonstrating that there is both equal amounts of matter-collecting (CG: 9\%; CLG: 29.2\%; CLMG: 8.3\%) and in different amount of matter-collecting or matter-deficit in parts of Zn electrode include also that there is not any change (CG: 27\%; CLG: 29.2\%; CLMG: $8.3 \%$ ) in parts of $\mathrm{Zn}$ electrode remaining outside of the solution. Some incorrect drawings by Students are given in Figure 4. 


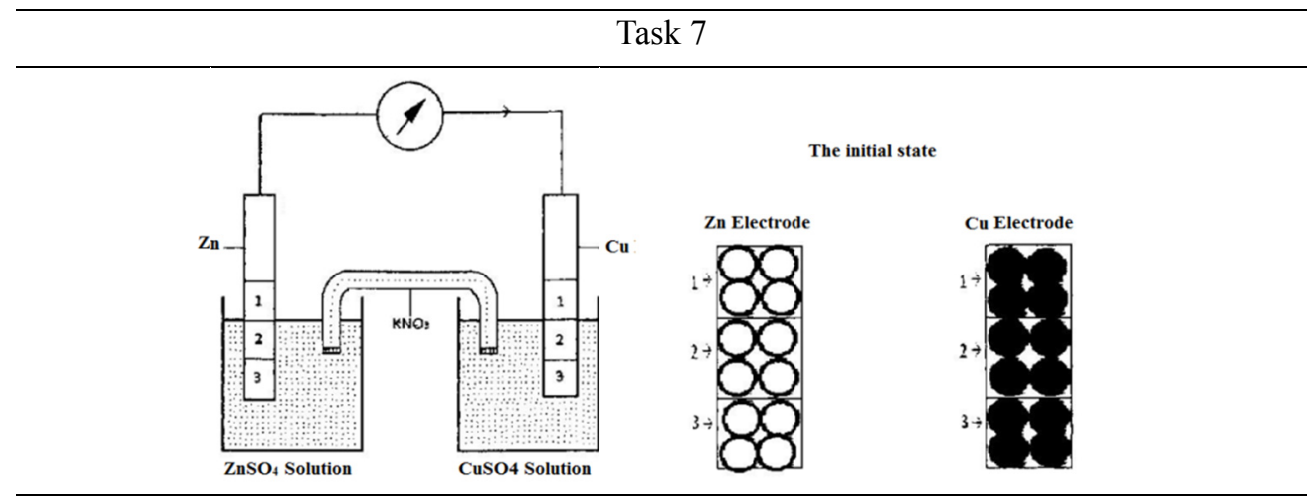

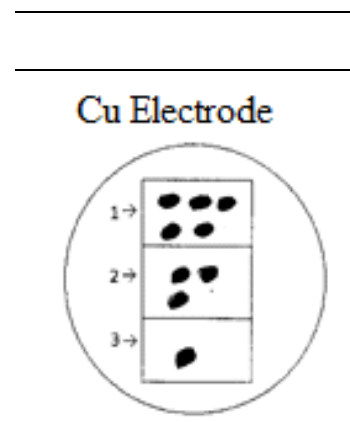

$\mathrm{Cu}$ Electrode

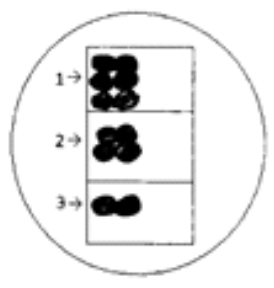

$\mathrm{Cu}$ Electrode

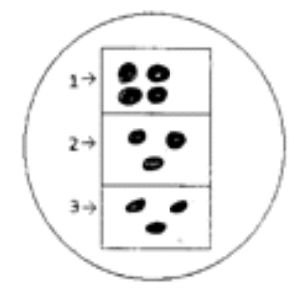

The Incorrect Drawings by Students

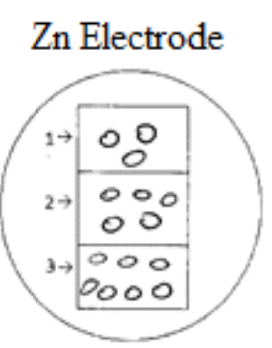

Zn Electrode

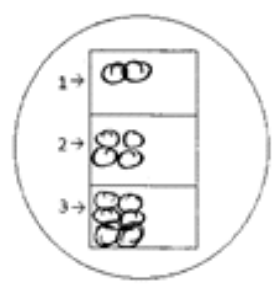

Zn Electrode

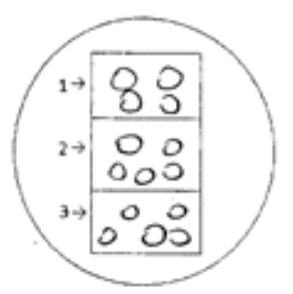

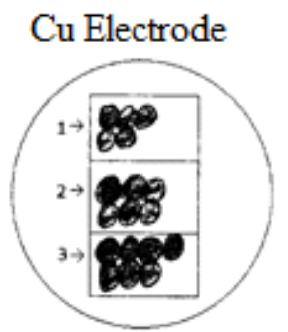

Zn Electrode

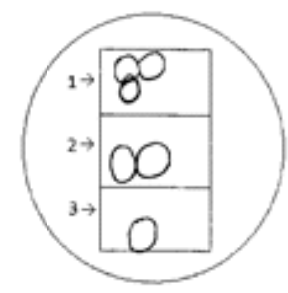

Zn Electrode

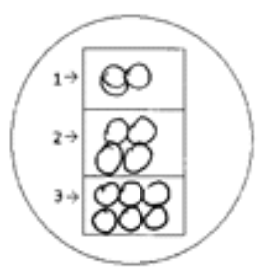

Zn Electrode
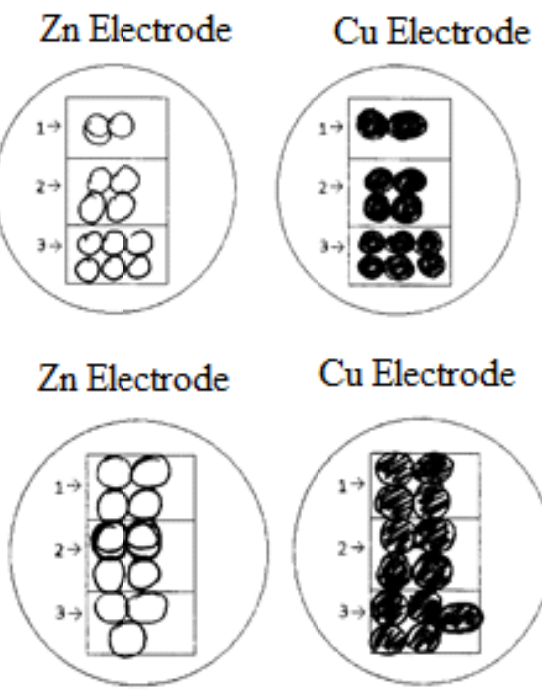

Figure 4. Some students' drawings in the misunderstanding category of Task 7 of the EcAT

\section{Conclusion and Discussion}

The aim of this study was "to determine students' level of learning by applying three different teaching methods" in the teaching of the electrochemical cells. Both cognitive learning and constructivist learning theory have brought to the forefront and the idea that new information is constructed over prior knowledge of students (Kwan \& Wong, 2015). Starting from this point of view, preliminary knowledge of the students who participated in the research in the electrochemical cells were determined prior to the application in order to discover the effect of teaching methods used in research and to be able to compare the research groups, and it was determined that preliminary knowledge of research groups are different (Table 2). These differences may be due to the fact that students with a background in science. Students come to university from different regions of Turkey and different school types and from differences in their academic learnings in high school level related to these subjects (electrochemical cells). The effect of differences in pre-test scores of students in the research groups on the dependent variables of the research were taken under control by taking EcAT pre-test scores as covariates.

Considering the findings derived from statistical analysis of EcAT post-test scores of the students who participated in the application in the electrochemical cells; it was concluded that STAD method along with the 
models used in the teaching of the electrochemical cells, is more effective in increasing student academic achievement compared to only STAD method and the traditional method of teaching. Furthermore, it was concluded that the effect of teaching of the electrochemical cells only by STAD method and the traditional method of teaching on the academic success of students is approximately equal. It was found that the methods used in teaching of the electrochemical cells have a high effect $(\mathrm{f}=0.47)$ on academic achievement of students in electrochemical subjects.

In this research, only the Student Teams Achievement Divisions cooperative learning method was used in a group, and along with models in another group. The results of research showed that the STAD method used along with models is more effective for students to understand electrochemical cells. The reason of positive learning effect resulted from using model in addition to cooperative learning, may be that the models used in teaching have enabled both representational and referential encoding facilities in accordance with the dual coding theory. The fact that Models' being used in teaching in this way is effective in teaching of scientific facts, states of affairs, concepts and principles were put forward also in researches (Mayer, 2003; Moreno \& Valdez, 2005). In this study, support is provided to the students, who have been studying in cooperative learning groups, by using models for them to understand visual processes (contents) in the electrochemical cells at the molecular (particulate) level.

The results of this research related to that "supporting the education with models provides higher academic achievement" are consistent with the results of the research (Adadan, 2014b; Ardac \& Akaygun, 2004; Liu, 2006; MacKinnon, 2003; Merritt et al., 2007; Saari \& Viiri, 2003; Schwartz \& White, 2005; Snir et al., 2003). The results of performed researches show that using models in teaching of general chemistry subjects, especially in teaching of electrochemistry subjects, help to revive events that occur at the micro level in electrochemical cell and is effective in removing misconceptions (Ealy, 2004; Huddle et al., 2000; Liu, 2006).

The result of the research, "only STAD cooperative learning and traditional teaching method used in teaching have a similar effect on students' understanding of the electrochemical cells" is different from the results of the performed researches. Researches showed that STAD is more effective in increasing students' achievements, attitudes, motivation, social skills and self-sufficiency compared to traditional method, and that it strengthens learning scientific concepts (Bilgin, Aktaş, \& Çetin, 2014; Gencosman \& Doğru, 2012; İbraheem, 2011; Novianti, 2013; Tiantong \& Teemuangsai, 2013; Ural et al., 2008; Ünlü \& Aydıntan, 2011; Wyk, 2012; Zakaria et al., 2010). However, the result obtained in this research is in consistency with the findings of Khan and Inamullah (2011) and Topsakal (2010) stating that cooperative learning method does not significantly increase the achievement compared to traditional teaching method.

From the answers that research groups have given to questions in EcAT requiring visualization at particulate level, the findings related to the answers except those considered scientifically correct, showed that students in all groups have some misunderstandings in the electrochemical cells. It was found that students in each of the three groups have misunderstanding as there is not any ion pass from salt bridge to anode and cathode sections in order to ensure load balance while electrochemical cell is working. It was seen that some students know that there will be ion pass from salt bridge to anode and cathode sections while electrochemical cell is working but they do not understand that it is in order to ensure load balance (MU Category of Task 1 on EcAT).

In Task 7, it was reached to the conclusion that students have misunderstandings as there will be matter-collecting or matter-deficit in parts of the electrodes $(\mathrm{Zn}$ and $\mathrm{Cu}$ ) marked as three parts (I: Upper, II: Middle and III: Lower), which are used in the anode and cathode sections of zinc-copper electrochemical cell, remained out of the solution. Also it was found that students have misunderstandings as there will be a different amount of matter-collecting or matter-deficit in parts of the electrodes which remain in the solution, as well (MU Category of Task 7 on EcAT). In this research, it was found that these misunderstandings are in lower levels of the student groups to which STAD cooperative learning method was applied along with models compared to other groups. These results supports the conclusion that STAD cooperative learning method along with models put forth by statistical analysis is more effective in students' understanding electrochemistry subjects (Table 3). However, use of models in teaching could not be fully effective in removing misunderstandings of the students, either. This situation may have resulted from the realization of electrochemical processes at the molecular level and students have learnt mainly from the conceptual level. Whereas, it was seen that understanding electrochemical processes of the students in the groups in which only cooperative learning STAD method and traditional teaching method have been used are in much lower level. The reason for this may be that the students in these groups conducted their learning subjects from materials that they can get through text based sources and that they have tried to understand the molecular processes by using materials containing two-dimensional diagrams and pictures. 
To conclude, in this study, support was provided to students for them to understand electrochemical processes occurring by using models along with cooperative learning. It was concluded that cooperative learning is effective in increasing achievement of students along with the models used in this research. Based on these results, we believe that teachers and researchers can use the method of cooperative learning student team achievement divisions along with the models in teaching of chemistry subjects containing processes that occur at the molecular level.

\section{References}

Abraham, M. R., Grzybowski, E. B., Renner, J. W., \& Marek, E. A. (1992). Understandings and misunderstandings of eight graders of five chemistry concepts found in textbooks. Journal of Research in Science Teaching, 29(2), 105-120. http://dx.doi.org/10.1002/tea.3660290203

Adadan, E. (2014a). Investigating the influence of pre-service chemistry teachers' understanding of the particulate nature of matter on their conceptual understanding of solution chemistry. Chemistry Education Research and Practice, 15, 219-238. http://dx.doi.org/10.1039/C4RP00002A

Adadan, E. (2014b). Investigating the effect of model-based learning environment on preservice chemistry teachers' understadings of the particle theory of matter and the nature of scientific models. OMÜ Ĕgt. Fak. Derg. [OMU J. Fac. Educ.], 33(2), 378-403. http://dx.doi.org/10.7822/omuefd.33.2.5

Adadan, E., Irving, K. E., \& Trundle, K. C. (2009). Impacts of multi-representational instruction on high school students' conceptual understandings of the particulate nature of matter. International Journal of Science Education, 31(13), 1743-1775. http://dx.doi.org/10.1080/09500690802178628

Adesoji, F. A., \& Ibraheem, T. L. (2009). Effects of students teams-achievement divisions strategy and mathematics knowledge on learning outcomes in chemical kinematics. Journal of International Social Research, 2(6), 15-25.

Ardac, D., \& Akaygun, S. (2004). Effectiveness of multimedia based instruction that emphasizes molecular representations on students' understanding of chemical change. Journal of Research in Science Teaching, 4l(4), 317-337. http://dx.doi.org/10.1002/tea.20005

Aydoğdu, S. (2012). Üniversite ögretim elemanlarının Chickering ve Gamson öğrenme ilkelerini kullanma düzeyleri [The level of practising Chickering and Gamson learning principles of instructors] (Unpublished master's thesis). Atatürk University, Erzurum.

Bilgin, İ., Aktaş, İ., \& Çetin, A. (2014). The effect of student-team achievement division technique on mental ability of elementary students. Elementary Education Online, 13(4), 1352-1372.

Brown, K., \& Cole, M. (2000). Socially-shared cognition: System design and the organization of collaborative research. In D. H. Jonasssen, \& S. L. Land (Eds.), Theoretical foundations of learning environments (pp. 197-214). Mahwah, NJ: Erlbaum.

Çalık, M., \& Ayas, A. (2005). A comparison of level of understanding of eighth-grade students and science student teachers related to selected chemistry concepts. Journal of Research in Science Teaching, 42(6), 638-667. http://dx.doi.org/10.1002/tea.20076

Chan, K. W. (2014) Cooperative learning in a Hong Kong primary school: perceptions, problems and accommodation. Intercultural Education, 25(3), 216-228. http://dx.doi.org/10.1080/14675986.2014.911805

Cohen, J. (1988). Statistical power analysis for the behavioral sciences (2nd ed.). Hillsdale, NJ: Lawrence Earlbaum Associates.

Creswell, J. W. (2014). Research Design: Qualitative, Quantitative, and Mixed Methods Approach (4th ed.). London: SAGE Publications, Inc.

Doymus, K., Karacop, A. \& Simsek, U. (2010). Effects of jigsaw and animation techniques on students' understanding of concepts and subjects in electrochemistry. Education Tech Research Dev, 58, 671-691. http://dx.doi.org/10.1007/s11423-010-9157-2.

Ealy, J. B. (2004). Students' understanding is enhanced through molecular modeling. Journal of Science Education and Technology, 13(4), 461-471. http://dx.doi.org/10.1007/s10956-004-1467-x

Ekiz, B., Kutucu, E. S., Akkus, H., \& Boz, Y. (2011). Pre-service chemistry teachers' understanding of electrolytic cells. Psillos D. and Sperandeo RM, Proceedings of the European Science Education Research Association (ESERA 2011): Science Learning and Citizenship (Part 12: Pre-service science teacher education), ESERA, 51-54. 
Erlandson, B. E., Nelson, B. C., \& Savenye, W. C. (2010). Collaboration modality, cognitive load, and science inquiry learning in virtual inquiry environments. Educational Technology Research and Development, 58(6), 693-710. http://dx.doi.org/10.1007/s11423-010-9152-7

Garnett, P. J. \& Treagust, D. F. (1992b). Conceptual difficulties experienced by senior high school students of electrochemistry: Electrochemical (galvanic) and electrolytic cells. Journal of Research in Science Teaching, 29(10), 1079-1099. http://dx.doi.org/10.1002/tea.3660291006

Garnett, P. J., \& Treagust, D. F. (1992a). Conceptual difficulties experienced by senior high school students of electrochemistry: Electric circuits and oxidation-reduction equations. Journal of Research in Science Teaching, 29(2), 121-142. http://dx.doi.org/10.1002/tea.3660290204

Gencosman, T., \& Doğru, M. (2012). Effect of student teams-achievement divisions technique used in science and technology education on self-efficacy, test anxiety and academic achievement. Journal of Baltic Science Education, 11(1), 43-54.

Gilbert, J. K. (2005). Visualization: A metacognitive skill in science and science education. In J. K. Gilbert (Ed.), Visualization in science education (pp. 9-27). Netherlands: Springer. http://dx.doi.org/10.1007/1-4020-3613-2.

Huddle, P. A., White, M. D., \& Rogers, F. (2000). Using a teaching model to correct known misconceptions in electrochemistry. Journal of Chemical Education, 77(1), 104-110. http://dx.doi.org/10.1021/ed077p104

Ibraheem, T. L. (2011, December). Effects of two modes of student teams-achievement division strategies on senior secondary school students' learning outcomes in chemical kinetics. In Asia-Pacific Forum on Science Learning and Teaching (Vol. 12, No. 2, pp. 1-21). Hong Kong Institute of Education. 10 Lo Ping Road, Tai Po, New Territories, Hong Kong.

Jalilifar, A. (2010). The effect of cooperative learning techniques on college students' reading comprehension. System, 38(1), 96-108. http://dx.doi.org/10.1016/j.system.2009.12.009

Johnson, D. W., \& Johnson, R. (2005). New Developments in Social Interdependence Theory. Genetic, Social, \& General Psychology Monographs, 131(4), 285-358. http://dx.doi.org/10.3200/MONO.131.4.285-358

Johnson, D. W., \& Johnson, R. T. (2014). Cooperative Learning in 21st Century. Anales De Psicología, 30(3), 841-851. http://dx.doi.org/10.6018/analesps.30.3.201241

Kapur, M., \& Kinzer, C. K. (2007). Examining the effect of problem type in a synchronous computer supported collaborative learning (CSCL) environment. Educational Technology, Research and Development, 55, 439-459. http://dx.doi.org/10.1007/s11423-007-9045-6

Karacop, A., \& Doymus, K. (2013). Effects of jigsaw cooperative learning and animation techniques on students' understanding of chemical bonding and their conceptions of the particulate nature of matter. Journal of Science Education Technology, 22, 186-203. http://dx.doi.org/10.1007/s10956-012-9385-9

Karsli, F., \& Çalik, M. (2012). Can freshman science student teachers' alternative conceptions of 'electrochemical cells' be fully diminished? Asian Journal of Chemistry, 24(2), 485-491.

Khan, G. N., \& Inamullah, H. M. (2011). Effect of student's team achievement division (STAD) on academic achievement of students. Asian Social Science, 7(12), 211-215. http://dx.doi.org/10.5539/ass.v7n12p211

Kwan, Y. W., \& Wong, A. F. (2015). Effects of the constructivist learning environment on students' critical thinking ability: Cognitive and motivational variables as mediators. International Journal of Educational Research, 70, 68-79. http://dx.doi.org/10.1016/j.ijer.2015.02.006

Lee, T. T., \& Osman, K. (2011). Effectiveness of interactive multimedia module with pedagogical agent (IMMPA) in the learning of electrochemistry: A preliminary investigation. Asia-Pacific Forum on Science Learning and Teaching, 12(2), 1-24.

Lin, H. S., Yang, T. C., Chiu, H. L., \& Chou, C. Y. (2002). Students' difficulties in learning electrochemistry. Proceedings of the National Science Council R.O.C.: Part D, 12(3), 100-105.

Liu, X. (2006). Effects of combined hands-on laboratory and computer modeling on student learning of gas laws: A quasi-experimental study. Journal of Science Education and Technology, 15(1), 89-100. http://dx.doi.org/10.1007/s10956-006-0359-7

Loh, A. S. L., Subramaniam, R., \& Tan, K. C. D. (2014). Exploring students' understanding of electrochemical cells using an enhanced two-tier diagnostic instrument, Research in Science \& Technological Education, 
32(3), 229-250, http://dx.doi.org/10.1080/02635143.2014.916669

MacKinnon, G. (2003). Why models sometimes fail. Journal of College Science Teaching, 32(7), 430-433. http://dx.doi.org/10.2505/4/jcst03_032_07_430

Mayer, R. E. (2003). The promise of multimedia learning: using the same instructional design methods across different media. Learning and Instruction, 13, 125-139. http://dx.doi.org/10.1016/S0959-4752(02)00016-6

Merritt, J., Shwartz, Y., \& Krajcik, J. (2007). Middle school students' development of the particle model of matter. Paper presented at the Annual Meeting of the National Association for Research in Science Teaching. New Orleans, LA.

Moreno, R. (2009). Constructing knowledge with an agent-based instructional program: A comparison of cooperative and individual meaning making. Learning and Instruction, 19, 433-444. http://dx.doi.org/10.1016/j.learninstruc.2009.02.018

Moreno, R., \& Valdez, F. (2005). Cognitive load and learning effects of having students organize pictures and words in multimedia environments: The role of student interactivity and feedback. Educational Technology Research and Development, 53(3), 35-45. http://dx.doi.org/10.1007/BF02504796

Novianti, I. (2013). Experimentation cooperative learning student team achievement division (STAD) type viewed from learning motivation. Asian Journal of Education and e-Learning, 01(05), 272-276.

Ogude, A. N. \& Bradley, J. D. (1994). Ionic conduction and electrical neutrality in operating electrochemical cells. Journal of Chemical Education, 71(1), 29-34. http://dx.doi.org/10.1021/ed071p29

Ogude, A. N., \& Bradley J. D. (1996). Electrode Processes and Aspects Relating to Cell Emf, Current, and Cell Components in Operating Electrochemical Cells. Journal of Chemical Education, 73(12), 1145-1149. http://dx.doi.org/10.1021/ed073p1145

Okur, N., \& Doymuş, K. (2012). The Effects of Group Investigation and Learning Together Techniques Applied in Teaching of Force and Motion Subjects on Students' Academic Achievements. Journal of Education Science Research, 2(1), 109-123.

Osman, K., \& Lee, T. T. (2014). Impact of interactive multimedia module with pedagogical agents on students 'understanding and motivation in the learning of electrochemistry. International Journal of Science and Mathematics Education, 12(2), 395-421. http://dx.doi.org/10.1007/s10763-013-9407-y

Özkaya, A. R. (2002). Conceptual difficulties experienced by prospective teachers in electrochemistry: Half-cell potential, cell potential, and chemical and electrochemical equilibrium in galvanic cells. Journal of Chemical Education, 79(6), 735-738. http://dx.doi.org/10.1021/ed079p735

Papageorgiou, G., Stamovlasis, D., \& Johnson, P. (2013). Primary teachers' understanding of four chemical phenomena: Effect of an in-service training course. Journal of Science Teacher Education, 24, 763-783. http://dx.doi.org/10.1007/s10972-012-9295-y

Philipp, S. B., Johnson, D. K., \& Yezierski, E. J. (2014). Development of a protocol to evaluate the use of representations in secondary chemistry instruction. Chemistry Education Research and Practice, 15, 777-786. http://dx.doi.org/10.1039/C4RP00098F

Russell, J., \& Kozma, R. B. (2005). Assessing learning from the use of multimedia chemical visualization software. In J. K. Gilbert (Ed.), Visualization in science education (pp. 299-322). Netherlands: Springer. http://dx.doi.org/10.1007/1-4020-3613-2_15

Saari, H., \& Viiri, J. (2003). A research-based teaching sequence for teaching the concept of modeling to seventh-grade students. International Journal of Science Education, 25(11), 1333-1352. http://dx.doi.org/10.1080/0950069032000052081

Sanger, M. J., \& Greenbowe, T. J. (1997a). Common student misconceptions in electrochemistry: Galvanic, electrolytic, and concentration cells. Journal of Research in Science Teaching, 34(4), 377-398. http://dx.doi.org/10.1002/(SICI)1098-2736(199704)34:4<377::AID-TEA7>3.3.CO;2-E

Sanger, M. J., \& Greenbowe, T. J. (1997b). Students' misconceptions in electrochemistry: Current flow in electrolyte solutions and the salt bridge. Journal of Chemical Education, 74, 819-823. http://dx.doi.org/10.1021/ed074p819

Schwarz, C., \& White, B. (2005). Metamodeling knowledge: Developing students' understanding of scientific modeling. Cognition and Instruction, 23, 165-205. http://dx.doi.org/10.1207/s1532690xci2302_1 
Sharan, Y. (2014). Learning to cooperate for cooperative learning. Anales De Psicología, 30(3), 802-807. http://dx.doi.org/10.6018/analesps.30.3.201211

Slavin, R. E. (2011). Instruction Based on Cooperative Learning. In R. E. Mayer, \& P. A. Alexander (Eds.), Handbook of Research on Learning and Instruction (pp. 344-360). New York: Taylor \& Francis.

Slavin, R. E. (2014). Cooperative learning and academic achievement: Why does groupwork work? Anales de psicología, 30(3), 785-791. http://dx.doi.org/10.6018/analesps.30.3.201201

Slavin, R. E. (2015). Cooperative learning in elementary schools, Education 3-13. International Journal of Primary, Elementary and Early Years Education, 43(1), 5-14, http://dx.doi.org/10.1080/03004279.2015.963370

Snir, J., Smith, C. L. \& Raz, G. (2003). Linking phenomena with competing underlying models: A software tool for introducing students to the particulate model. Science Education, 87, 794-830. http://dx.doi.org/10.1002/sce.10069

Supasorn, S., Khattiyavong, P., Jarujamrus, P., \& Promarak, V. (2014). Small-scale inquiry-based experiments to enhance high school students' conceptual understanding of electrochemistry, 4th International Conference on Education, Research and Innovation IPEDR, 81, 85-91. IACSIT Press, Singapore. $\mathrm{http}: / / \mathrm{dx}$. doi.org/10.7763/IPEDR.2014.V81.14.

Tasker, R., \& Dalton, R. (2006). Research into practice: Visualisation of the molecular world using animations. Chemistry Education Research and Practice, 7(2), 141-159. http://dx.doi.org/10.1039/B5RP90020D

Tiantong, M., \& Teemuangsai, S. (2013). Student team achievement divisions (STAD) technique through the moodle to enhance learning achievement. International Education Studies, 6(4), 85-92. http://dx.doi.org/10.5539/ies.v6n4p85

Topsakal, Ü. U. (2010). The Effectiveness of Cooperative Learning On Teaching 8th Class Unit 'Substance and Energy for Living Things'. Ahi Evran Üniversitesi Ë̆itim Fakültesi Dergisi [Ahi Evran University Journal of Kirşehir Education Faculty], 11(1), 91-104.

Tran, V. D. (2014). The Effects of Cooperative Learning on the Academic Achievement and Knowledge Retention. International Journal of Higher Education, 3(2), 131-140. http://dx.doi.org/10.5430/ijhe.v3n2p131

Tran, V. D., \& Lewis, R. (2012a). Effects of cooperative learning on students at an giang university in Vietnam. International Education Studies, 5(1), 86-99. http://dx.doi.org/10.5539/ies.v5n1p86

Tran, V. D., \& Lewis, R. (2012b). The effects of jigsaw learning on students' attitudes in a Vietnamese higher education classroom. International Journal of Higher Education, 1(2), 1-13. http://dx.doi.org/10.5430/ijhe.v1n2p9

Ünlü, M., \& Aydıntan, S. (2011). The views of 8th grade students related to students teams-achievement divisions technique in mathematics education. AİB̈̈, Ĕgitim Fakültesi Dergisi [Abant İzzet Baysal University Journal of Faculty of Education], 11(1), 101-117.

Ural, A., Umay, A., \& Argün, Z. (2008). The effect of students teams-achievement divisions method based instruction on mathematics academic achievement and self-efficacy. Hacettepe Üniversitesi Ë̆itim Fakültesi Dergisi (H. U. Journal of Education), 35, 307-318.

Wyk, M. M. (2012). The Effects of the STAD-cooperative learning method on student achievement, attitude and motivation in economics education. Journal of Social Sciences, 33(2), 261-270.

Zacharia, Z. C., Xenofontos, N. A., \& Manoli C. C. (2011). The effect of two different cooperative approaches on students' learning and practices within the context of a WebQuest science investigation. Education Tech Research Dev., 59, 399-424. http://dx.doi.org/10.1007/s11423-010-9181-2

Zakaria, E., Chin, L. C., \& Daud, Y. (2010). The effects of cooperative learning on students' mathematics achievement and attitude towards mathematics. Journal of Social Sciences, 6(2), 272-275. http://dx.doi.org/10.3844/jssp.2010.272.275 


\section{Copyrights}

Copyright for this article is retained by the author(s), with first publication rights granted to the journal.

This is an open-access article distributed under the terms and conditions of the Creative Commons Attribution license (http://creativecommons.org/licenses/by/4.0/). 